\title{
Evaluation of an enzyme-immunometric assay for serum $\alpha$-glutathione S-transferase
}

\author{
Gareth W Rees, Andrew K Trull and Sean Doyle ${ }^{1}$ \\ From the Department of Clinical Biochemistry, Level 4 Laboratories Block, \\ Addenbrooke's Hospital, Hills Road, Cambridge CB2 2QQ, UK and \\ 'Biotrin International, Stillorgan, Dublin, Ireland
}

\begin{abstract}
SUMmARY. A commercially available enzyme-immunometric assay for serum $\alpha$-glutathione S-transferase (GST) was evaluated. Endogenous serum $\alpha$-GST diluted linearly within the calibration range. However, we recommend that the sample and second antibody reagent are always added sequentially in the assay to avoid hook effect. Between-assay variability was below $7 \%$ across the calibration range and the upper limit of the reference range in adults $(n=219)$ was $11.4 \mu \mathrm{g} / \mathrm{L}$. Within-individual variability in serum $\alpha$-GST concentrations measured over a 4-6 week period in 4 healthy adults was small. Serum $\alpha$-GST concentrations did not change significantly $6 \mathrm{~h}$ after a therapeutic dose of paracetamol.

Studies in two patients after liver transplantation showed that serum $\alpha$-GST is a better discriminant of acute changes in liver function than conventional tests. Serum $\alpha$-GST concentrations were unaffected by gross muscle damage, extrahepatic inflammation, or haemolysis and thus appear to be more liver specific than transaminase activities. The effect of renal impairment on serum $\alpha$-GST concentrations requires further investigation.
\end{abstract}

Additional key phrases: serum $\alpha-G S T$; enzyme-immunometric assay; method validation; liver function; tissue specificity; ALT; AST

The glutathione S-transferases (GSTs) (E.C. 2.5.1.18) form a complex family of enzymes, primarily involved in the modification of xenobiotics and some endogenous substrates by catalysing their conjugation to reduced glutathione. Some may also exhibit seleniumindependent glutathione peroxidase activity. ${ }^{1,2}$ In man, $\alpha$-GST is found primarily within hepatocytes, comprising approximately $5 \%$ of the total soluble cytoplasmic protein mass, although it is also present in the kidney, adrenal gland and testis. ${ }^{3}$ It is a dimeric protein made up of two subunits $\left(B_{1}\right.$ and $\left.B_{2}\right)$ and may exist as a homodimer $\left(B_{1} B_{1}\right.$ and $\left.B_{2} B_{2}\right)$ or heterodimer $\left(B_{1} B_{2}\right)^{2} A$ genetically based nomenclature for GST has now been proposed ${ }^{4}$ distinguishing both the subunit composition of individual isoenzyme as well as allelic variants encoded at the same gene locus (denoted by capital letters). In this new

Correspondence: Dr A Trull. classification, the $\alpha$-class dimers described above are referred to as A1-1, A2-2 and A1-2, respectively. However, since most published research on GST has referred to $B_{1}$ and $B_{2}$ subunits, the latter designation is followed in this report.

The relatively small size of $\alpha$-GST (mol. $w t \approx 50000$ ) results in its rapid release following hepatocellular damage. This property, together with the restricted distribution of $\alpha$-class GST in tissues other than liver, the high concentration of the enzyme within hepatocytes, its short plasma half-life (approximately $1 \mathrm{~h}$ ) and wide distribution across the liver lobule should make $\alpha$-GST an ideal marker for monitoring acute changes in hepatocellular integrity. ${ }^{2}$ Monitoring $\alpha$-GST has been found to offer diagnostic and/or prognostic advantages over conventional liver function tests (LFTs) in a variety of acute clinical circumstances. ${ }^{5-13}$ Serum $\alpha$-GST concentrations also appear to correlate better with the histopathological 
features of chronic conditions such as chronic active hepatitis, even when conventional transaminase activities are normal. ${ }^{14-16}$

Published methods for the measurement of $\alpha$-GST have usually been either non-specific and susceptible to interference from endogenous substances (enzymatic assays) or too timeconsuming. ${ }^{2}$ However, a time-resolved immunofluorometric assay has recently been described. ${ }^{17}$ We have evaluated a commercial enzymeimmunometric assay for the quantitation of total serum $\alpha$-GST.

\section{MATERIALS AND METHODS}

\section{$\alpha$-GST enzyme-immunometric assay}

We used a commercially available enzymeimmunometric assay for the quantitation of serum $\alpha$-GST (Biotrin International, Stillorgan, Dublin, Ireland). Two procedures are described by the manufacturers and these are outlined below.

\section{Sequential assay procedure}

Stock calibration material was diluted in phosphate buffered saline with $0 \cdot 25 \% \mathrm{v} / \mathrm{v}$ Tween 20 (assay buffer) to yield concentrations in the range $1-50 \mu \mathrm{g} / \mathrm{L}$. Serum samples and quality control material were both diluted 1 in 5 in assay buffer. One hundred microlitres of appropriately diluted calibrators, quality controls and serum samples were added in duplicate to microtitre plates pre-coated with affinity purified polyclonal IgG antibody raised against purified total hepatic $\alpha$-GST (probably cross-reacting with all $\alpha$-GST dimeric forms). The assay plates were incubated at $25^{\circ} \mathrm{C}$ for $1 \mathrm{~h}$ with shaking (DSG Titretek plate shaker, speed 6). Then, the plate was washed four times with $200 \mu \mathrm{L}$ assay buffer and $100 \mu \mathrm{L}$ of the second antibody (polyclonal anti- $\alpha$-GST IgG conjugated to horseradish peroxidase) resuspended in assay buffer was added to each well. The plate was then incubated for a further hour at $25^{\circ} \mathrm{C}$ with shaking. After four further washes in assay buffer, $200 \mu \mathrm{L}$ of liquid tetramethylbenzidine substrate was added to each well and incubated for $10 \mathrm{~min}$ at $25^{\circ} \mathrm{C}$ with shaking. The reaction was then stopped with $50 \mu \mathrm{L} 1 \mathrm{M}$ sulphuric acid and the optical density read at $450 \mathrm{~nm}(650 \mathrm{~nm}$ reference) on a Vmax Kinetic Microplate Reader (NovoLabs). This sequential assay procedure was adhered to for all the studies described below unless stated otherwise.

\section{Simultaneous assay procedure}

Conditions were identical to the sequential assay protocol except that the addition of second antibody-HRP conjugate $(100 \mu \mathrm{L})$ followed the addition of $100 \mu \mathrm{L}$ of appropriately diluted serum samples, calibrators and quality control material and the incubation time was $1 \mathrm{~h}$. The simultaneous assay procedure was only followed in a comparison of linearity and precision with the sequential procedure.

\section{Assay performance \\ Linearity}

A serum sample from a liver transplant recipient with an $\alpha$-GST concentration of about $3000 \mu \mathrm{g} / \mathrm{L}$ was serially diluted and analysed by both sequential and simultaneous assay procedures in order to compare linearity.

\section{Precision profile}

Duplicate $\alpha$-GST measurements on clinical samples from 38 consecutive assays run on different days over a 2 month period were used to determine a precision profile across the calibration range. Duplicate values were classified into 12 concentration ranges (bins) and the bin mean, standard deviation and coefficient of variation calculated according to the method of Raggatt. ${ }^{18}$

\section{Intra- and inter-assay variability}

Alpha-GST was purified to homogeneity from human liver as verified by SDS-PAGE and isoelectric focusing. The absence of both $\mu$ - and $\pi$-GST was confirmed by Western blot analysis of the purified protein. This purified hepatic $\alpha$-GST was added to a pool of normal human serum to yield final concentrations of about $7 \cdot 5$, 25,50 and $125 \mu \mathrm{g} / \mathrm{L} \alpha$-GST and assayed 28 times in a single batch to assess intra-assay variability. Inter-assay variability was determined by analysing these samples in 24 consecutive assays (single kit batch), run on different days over a period of one month.

\section{Reference range and biological variability of $\alpha$-GST}

Blood samples were collected from 219 adult blood donors (aged 18 to 65 years) in order to determine the adult reference range. At least 15 sequential samples were collected at $09 \cdot 00 \mathrm{am}$ in the morning from each of four healthy adult volunteers over a period of between 34 and 42 days in order to provide a preliminary indication of the biological variability. 
Blood samples were also collected from eight healthy volunteers before and $6 \mathrm{~h}$ after the ingestion of $1 \mathrm{~g}$ paracetamol in order to assess the influence of a therapeutic dose on serum $\alpha$-GST concentrations.

\section{Tissue specificity studies}

Serum samples were collected from patients with a variety of clinical conditions in order to assess the tissue specificity of changes in serum $\alpha$-GST.

\section{Liver transplant recipients}

Sequential serum samples were prospectively collected from two liver allograft recipients to compare the characteristic pattern of changes in $\alpha$-GST and conventional LFTs seen during hepatocellular damage associated with acute allograft rejection following orthotopic liver transplantation.

\section{Patients with renal dysfunction}

Serum samples from 33 patients with normal liver function but elevated serum creatinine concentrations (median $383 \mu \mathrm{mol} / \mathrm{L}$; range 130 to $1364 \mu \mathrm{mol} / \mathrm{L}$ ) were collected following routine urea and electrolyte analysis.

\section{Patient with rhabdomyolysis}

Serial samples were collected from a patient with clinically documented rhabdomyolysis and a peak serum total creatinine kinase (CK) activity greater than 400 times the upper limit of the reference range.

\section{Patients with rheumatoid arthritis}

Serum samples were collected from 40 patients with rheumatoid arthritis: 20 with raised serum C-reactive protein (CRP) (median $31 \mathrm{mg} / \mathrm{L}$; range 8-104 mg/L) and 20 with normal serum CRP concentration $(<6 \mathrm{mg} / \mathrm{L})$. These were included primarily to assess the influence of extra-hepatic inflammatory disease on $\alpha$-GST measurements. Many of these samples were also known to contain high levels of IgM rheumatoid factor (up to $1250 \mathrm{IU} / \mathrm{mL}$ ) and, therefore, also served to assess any influence of this potential source of interference in the $\alpha$-GST immunoassay (see below).

\section{Interference studies}

The influence of potential endogenous interferents on serum $\alpha$-GST measurements was further investigated in a series of recovery experiments.

\section{Lipaemia}

Intra-lipid was added to normal human serum to give a triglyceride concentration of $63 \mathrm{mmol} / \mathrm{L}$.

\section{Icterus}

Five hundred microlitres, $100 \mathrm{mM} \mathrm{NaOH}$ containing $30 \mathrm{~g} / \mathrm{L}$ bovine serum albumin was saturated with unconjugated bilirubin (Sigma Chemical Company). This was diluted $1 / 100$ in an aliquot of the serum pool to give a pool with a bilirubin concentration of $591 \mu \mathrm{mol} / \mathrm{L}$.

\section{Haemolysis}

Freshly donated whole blood was lysed by repeated freeze-thawing giving a homogenous lysate with a haemoglobin concentration of $15 \cdot 2 \mathrm{~g} / \mathrm{dL}$.

The normal serum pool, icteric and lipaemic serum pools and the whole blood haemosylate was spiked to a target concentration of $100 \mu \mathrm{g} / \mathrm{L}$ purified human hepatic $\alpha$-GST. The three spiked pools containing the potential interferents were then mixed with the spiked normal serum pool to yield the following proportions of interferent$100 \%, 80 \%, 60 \%, 40 \%, 20 \%, 10 \%, 5 \%, 0 \%$. The recovery of spiked $\alpha$-GST in these serum mixtures was then measured.

\section{Paraproteins}

In our earlier study of $\alpha$-GST in liver allograft recipients, ${ }^{5}$ samples from one patient with a low concentration of serum IgM paraprotein appeared to be a source of assay interference. This interference was suspected from highly erratic changes in daily $\alpha$-GST measurements. This was investigated by assessing the recovery of purified $\alpha$-GST added to the patient's serum and to sera from non-transplant patients with known serum paraproteins of immunoglobulin classes IgG, IgA or IgM. The latter were selected to provide a broad range of paraprotein concentrations.

\section{RESULTS}

\section{Assay pereformance}

Figure 1 illustrates a marked 'hook effect' associated with high $\alpha$-GST concentrations in the simultaneous assay procedure-the maximum absorbance occurring at a concentration of approximately $60 \mu \mathrm{g} / \mathrm{L}$. By contrast, in the sequential assay the optical density reached a plateau at $\alpha$-GST concentrations above $100 \mu \mathrm{g} / \mathrm{L}$. In view of this finding, only the sequential procedure was used in all other evaluations. 


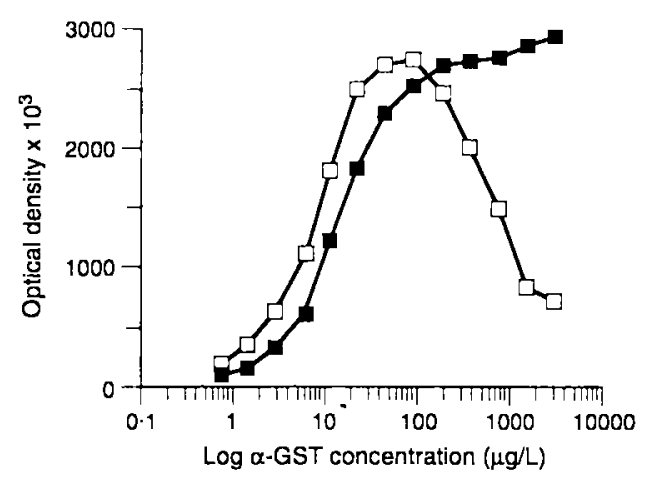

FigURE 1. Comparison of assay linearity for simultaneous $(\sqcap)$ and sequential ( $\square$ ) assay protocols. $G S T=$ glutathione S-transferase.

The detection limit assessed as the mean plus 2.5 times the standard deviation of eight $\alpha$-GST measurements of assay bufer alone was $0.5 \mu \mathrm{g} / \mathrm{L}$.

The precision profile is shown in Fig. 2. For all $\alpha$-GST concentrations within the range $0 \cdot 2$ to $50 \mu \mathrm{g} / \mathrm{L}$ (equating with serum GST concentrations of $1-250 \mu \mathrm{g} / \mathrm{L}$ ), the mean coefficient of variation was less than $6 \%$.

Table 1 shows the results of the precision study. The inter-assay coefficient of variation (CV) only exceeded $10 \%$ at a concentration of $7 \cdot 5 \mu \mathrm{g} / \mathrm{L}$ (Table 1).

\section{Reference range and biological variability of $\alpha$-GST}

Serum $\alpha$-GST concentrations were log-normally distributed and the upper limit of the reference range (logarithmic mean $+2 \mathrm{SD}$ ) was $11 \cdot 4 \mu \mathrm{g} / \mathrm{L}$.

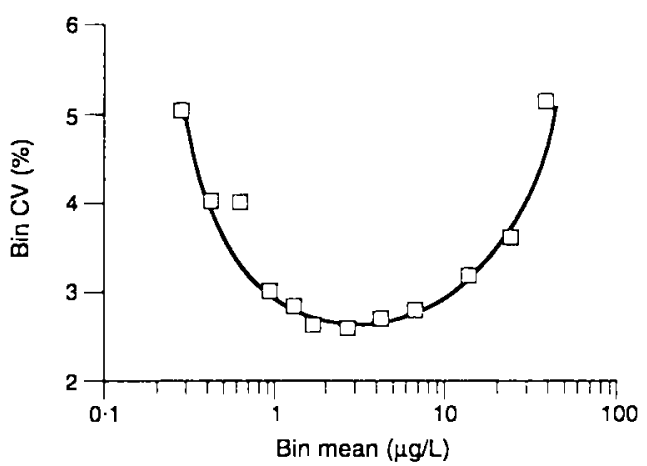

FIGURE 2. Precision profile for the sequential assay determined by the analysis of variability between sample duplicates. Bin $=$ concentration range; $C V=$ coefficient of variation.

In all four healthy individuals monitored sequentially, the median morning serum $\alpha$-GST concentration was $2 \mu \mathrm{g} / \mathrm{L}$ (range $1-4 \mu \mathrm{g} / \mathrm{L}$ ). In the longest series of 18 sequential samples, collected from one individual over a period of 34 days, the mean (SD) serum $\alpha$-GST concentration was $2 \cdot 2(0 \cdot 4) \mu \mathrm{g} / \mathrm{L}$. There was no detectable pattern within individuals.

Serum $\alpha$-GST concentrations did not change significantly $6 \mathrm{~h}$ after a therapeutic dose of paracetamol $(3 \cdot 5 \pm 3 \cdot 5 \mu \mathrm{g} / \mathrm{L}$ pre-dose and $3 \cdot 2 \pm 2 \cdot 5 \mu \mathrm{g} / \mathrm{L}$ post-dose).

\section{Tissue specificity and interference studies}

The results of conventional LFTs and $\alpha$-GST measurements following liver transplantation in two patients are shown in Fig. $3(a, b)$. Both patients experienced episodes of acute allograft rejection within the first post-operative month.

TABLE 1. Inter- $(\mathrm{n}=24)$ and intra-assay $(\mathrm{n}=28)$ variability for the sequential assay protocol

\begin{tabular}{lrrrr}
\hline \multirow{2}{*}{$\begin{array}{l}\text { Concentration of } \alpha \text {-GST added } \\
(\mu \mathrm{g} / \mathrm{L})\end{array}$} & \multicolumn{4}{c}{ Purified $\alpha$-GST added to serum pool } \\
\cline { 2 - 5 } & $7 \cdot 5$ & $25 *$ & 50 & 125 \\
\hline $\begin{array}{l}\text { Measured } \alpha \text {-GST concentration } \\
\text { Inter-assay }\end{array}$ & & & & \\
$\quad$ Mean & $7 \cdot 9$ & $25 \cdot 1$ & $58 \cdot 2$ & $135 \cdot 0$ \\
SD & $1 \cdot 1$ & $1 \cdot 4$ & $3 \cdot 5$ & $6 \cdot 4$ \\
CV (\%) & $14 \cdot 2$ & $5 \cdot 5$ & $6 \cdot 1$ & $4 \cdot 8$ \\
Intra-assay & & & & \\
Mean & $6 \cdot 3$ & $30 \cdot 9$ & $54 \cdot 6$ & $124 \cdot 0$ \\
SD & $0 \cdot 2$ & $1 \cdot 0$ & $1 \cdot 2$ & $5 \cdot 8$ \\
CV (\%) & $2 \cdot 9$ & $3 \cdot 1$ & $2 \cdot 2$ & $4 \cdot 7$ \\
\hline
\end{tabular}

* Two separate human serum pools were used to assess inter- and intra-assay variability. 

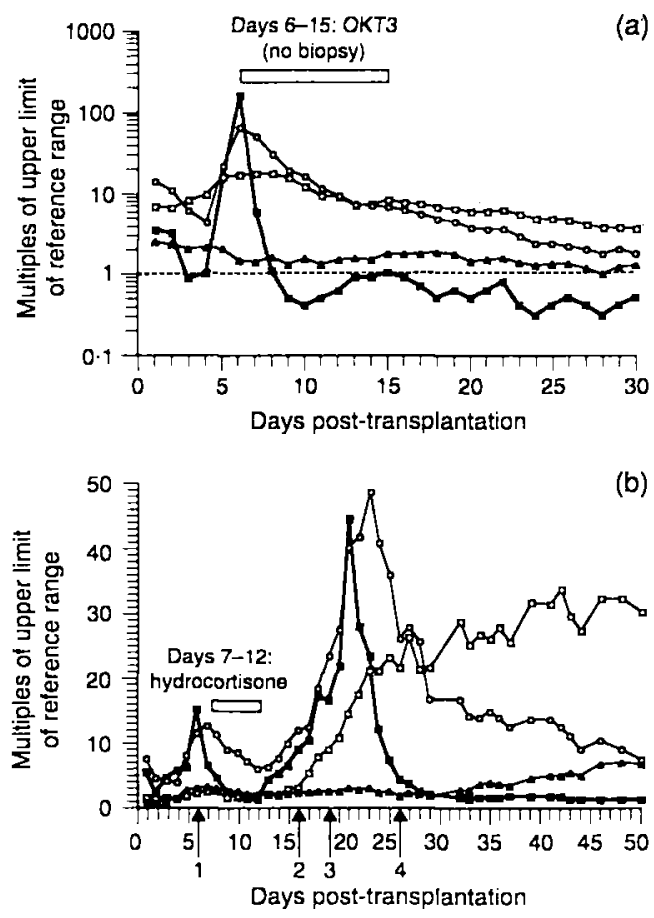

FIGURE 3. Longitudinal changes in serum $\alpha$ glutathione S-transferase (GST, ฯ), bilirubin (BILI, $\square)$, alkaline phosphatase (ALP, $\triangle)$ and alanine transaminase (ALT, O) measurements in two patients ( $a$ and b) following orthotopic liver transplantation. All results are expressed as multiples of the upper limit of the respective reference range (broken line). (b) Biopsy findings (arrowed): (1) moderate rejection (treated); (2) mild rejection (no treatment); (3) mild/moderate rejection plus necrosis; (4) resolved acute rejection.

In the first patient $(a)$, all LFTs exceeded their respective reference ranges in the immediate post-operative period but only $\alpha$-GST fell to within the reference range by day 3 . Subsequently, there was a marked rise in $\alpha$-GST as well as alanine transaminase (ALT) and bilirubin. This was associated with an episode of acute allograft rejection diagnosed clinically on day 6 which was successfully treated with the monoclonal anti-T cell antibody OKT3. Consistent with the resolution of rejection, $\alpha$-GST concentrations fell rapidly to within the reference range by the third day of therapy and remained there throughout the first post-operative month. Conventional LFTs, however, failed to return to the reference range during this time.

Similar biochemical changes were seen in the second patient (Fig. 3b) in association with an early rejection episode on day 6. In this case, $\alpha$-GST concentration increased two days earlier than conventional LFTs and 4 days prior to the histological diagnosis of rejection. Unlike ALT, serum $\alpha$-GST fell rapidly to normal during augmented immunosuppression. Serum $\alpha$-GST increased again on the thirteenth day, 1 day prior to a rise in ALT and 3 days prior to recurrent but apparently milder rejection. In the absence of treatment, rejection persisted and $\alpha$-GST continued to increase in parallel with conventional LFTs. Eventually, the mild/moderate rejection appeared to resolve spontaneously without treatment and there was a corresponding rapid fall in $\alpha$-GST and subsequent much slower fall in ALT. The persistent increase in bilirubin and ALP was compatible with the development of early chronic rejection in this patient.

In patients with renal dysfunction but normal conventional LFTs, no correlation was found between serum creatinine and $\alpha$-GST concentrations. Serum $\alpha$-GST concentrations were outside the reference range in two samples and serum creatinine concentrations in these cases were only marginally abnormal. The patient with the highest serum $\alpha$-GST was receiving digoxin therapy but also had the highest serum ALT activity of $48 \mathrm{IU} / \mathrm{L}$ (upper limit of reference range $50 \mathrm{IU} / \mathrm{L}$ ) in this group of patients. There was no clinical explanation for the raised $\alpha$-GST concentration in the second patient.

Serial total CK and ALT activities as well as $\alpha$-GST concentrations in a patient with rhabdomyolysis are shown in Fig. 4. Serum $\alpha$-GST concentrations remained within the

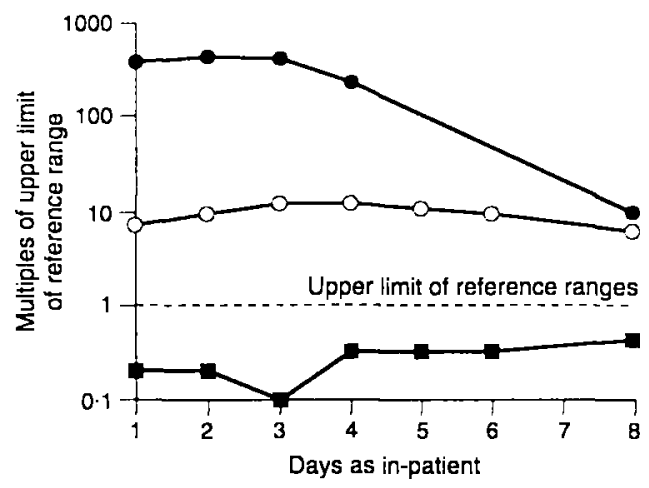

FIGURE 4. Longitudinal changes in serum creatinine kinase $(C K, 0)$, alanine transaminase $(A L T, 0)$ and $\alpha$-glutathione $S$-transferase (GST, $\square$ ) measurements in a patient with clinically diagnosed rhabdomyolysis. 
reference range, despite abnormal concentrations of ALT. Aspartate transaminase (AST) $\gamma$ glutamyltransferase (GGT) activities measured on the day of maximal CK activity $(83300 \mathrm{U} / \mathrm{L}$ : upper limit of reference range $195 \mathrm{U} / \mathrm{L}$ ) were found to be $2121 \mathrm{U} / \mathrm{L}$ (upper limit of reference range $40 \mathrm{U} / \mathrm{L}$ ) and $8 \mathrm{U} / \mathrm{L}$ (upper limit of reference range $38 \mathrm{U} / \mathrm{L}$ ), respectively. Serum bilirubin and alkaline phosphatase measurements remained within their reference ranges throughout the patient's hospitalization.

Serum $\alpha$-GST concentrations in rheumatoid arthritis patients with a raised serum CRP were not significantly different from either rheumatoid arthritis patients with a low CRP or healthy controls. However, four patients with a low CRP had serum $\alpha$-GST concentrations greater than twice the upper limit of the reference range (27, 34,42 , and $83 \mu \mathrm{g} / \mathrm{L}$ ) and all had particularly high IgM rheumatoid factor titres $(214,344,1060$, and $1250 \mathrm{IU} / \mathrm{mL}$, respectively). Assay interference was confirmed in the first and last of these four samples, from the non-linear decrease in measured $\alpha$-GST concentration upon serum dilution and from a 25 to $50 \%$ over-recovery of purified $\alpha$-GST added to these samples. Serum $\alpha$-GST concentrations were significantly higher in patients with rheumatoid factor titres greater than $70 \mathrm{IU} / \mathrm{L}$ (Fig. 5).

There appeared to be some under-recovery of $\alpha$-GST in the presence of bilirubin (mean recovery 94\%; 95\% confidence interval (CI) 89-99\%). However, there was no systematic increase in recovery as bilirubin was diluted out. There was

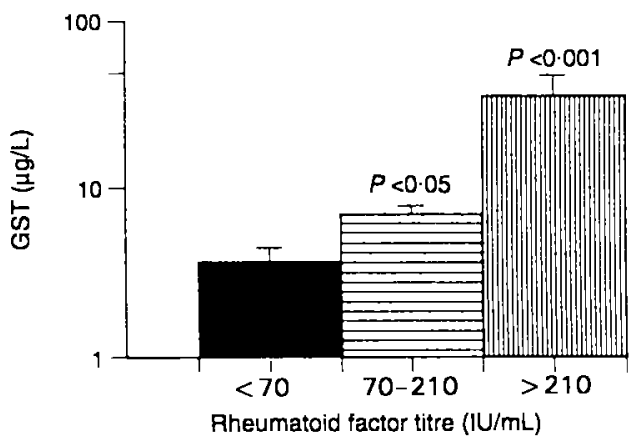

FIGURE 5. Serum $\alpha$-glutathione S-transferase (GST) concentrations in patients with rheumatoid arthritis according to the titres of serum rheumatoid factor (titres below $70 \mathrm{IU} / \mathrm{L}(\mathrm{n}=15), 70$ to $210 \mathrm{IU} / \mathrm{L}(\mathrm{n}=6)$ and greater than $210 \mathrm{IU} / \mathrm{L}(\mathrm{n}=6))$. Statistical differences between groups were determined by Student's t-test. no significant interference by either lipaemia (mean recovery $101 \% ; 95 \%$ CI $98-104 \%$ ) or haemolysis (mean recovery 102\%; 95\% CI 99-105\%).

Suspected assay interference by serum from a liver transplant recipient with an IgM paraprotein was confirmed by a 100 to $300 \%$ over-recovery of purified $\alpha$-GST added to the patient's serum sample. However, eight further samples from non-transplant patients with IgG $(n=4)$, $\operatorname{IgA}(n=1)$ and $\operatorname{IgM}(n=3)$ paraproteins at concentrations ranging from 10 to $64 \mathrm{~g} / \mathrm{L}$ did not interfere in the measurement of $\alpha$-GST.

\section{DISCUSSION}

We have evaluated a commercially available enzyme immunometric assay for the quantitation of total $\alpha$-GST concentrations in human serum. Most published methods for measuring $\alpha$-GST detect specific $\alpha$-GST subunits whereas the antiserum used here was raised against total hepatic $\alpha$-GST and, therefore, probably detects all $\alpha$-GST dimeric forms. The relative clinical merits of measuring specific or total $\alpha$-GST subunits has not been established although the use of antiserum that reacts with specific $\alpha$-GST subunits has been advocated because the proportion of $B_{1} B_{2}$ heterodimer in liver can vary markedly. ${ }^{2}$ In a previous study we have demonstrated the high sensitivity of the immunometric assay for monitoring hepatocellular integrity after human liver transplantation. ${ }^{5}$ However, that study did not assess the organ specificity of serum total $\alpha$-GST or involve any technical validation of the assay.

We recommend that the sequential assay protocol is followed since the simultaneous assay procedure results in a marked high dose 'hook effect' at serum $\alpha$-GST concentrations greater than $60 \mu \mathrm{g} / \mathrm{L}$ (equivalent to $300 \mu \mathrm{g} / \mathrm{L}$ in serum).

The upper limit of the reference range for serum $\alpha$-GST by this method was $11.4 \mu \mathrm{g} / \mathrm{L}$; three to six times higher than that quoted for methods that detect specific homodimers of the enzyme (see Ref. 2). This probably reflects the fact that the antiserum used in the current method was raised against total hepatic $\alpha$-GST. Serial morning $\alpha$-GST concentrations measured over periods of 4-6 weeks in healthy adult volunteers showed very little variation. Further studies are warranted, however, to more fully assess the biological variability in serum $\alpha$-GST. Such reproducibility is particularly important when monitoring daily changes in liver function. 
Serum $\alpha$-GST concentrations were unperturbed $6 \mathrm{~h}$ after a single therapeutic $(1 \mathrm{~g})$ dose of paracetamol. The measurement of serum $\alpha$-GST at later time points after the dose will be necessary to confirm this result but previous studies have shown that patients who required treatment for paracetamol overdose consistently had raised serum $\alpha$-GST as early as $4 \mathrm{~h}$ after the dose. ${ }^{2}$ One of the potential applications of serum $\alpha$-GST is likely to be in the pharmaceutical industry to monitor drug hepatotoxicity. However, it will be necessary to examine the effect of repeated therapeutic doses of paracetamol as well as other commonly used potentially hepatotoxic drugs on serum $\alpha$-GST before this possibility can be realized.

We followed two adult liver transplant recipients longitudinally and a rise in $\alpha$-GST was associated with episodes of acute liver allograft rejection confirming our previous observations. ${ }^{5}$ In the second case, persistent mild rejection appeared to resolve spontaneously and $\alpha$-GST concentrations fell accordingly to normal-remaining within the reference range despite the development of chronic allograft dysfunction. Compatible with the short in vivo half-life of $\alpha$-GST (about $1 \mathrm{~h}$ ), we found that concentrations of the enzyme fell more rapidly than conventional LFTs both immediately after successful transplantation and during resolution of rejection. This illustrates the potential value of this test.

The relatively restricted distribution of the enzyme in human tissues ${ }^{3}$ could theoretically offer advantages over conventional LFTs. Indeed, serial measurements of $\alpha$-GST were found to remain persistently normal in a patient with clinical rhabdomyolysis and serum creatine kinase (CK) activities of up to $80000 \mathrm{U} / \mathrm{L}$, accompanied by markedly raised serum ALT and AST activities despite the absence of any other clinical or biochemical evidence of hepatocellular damage. Numerous studies in both animals ${ }^{19,20}$ and humans ${ }^{21,22}$ suggest that such elevated serum transaminase activities are due to release of muscle isoforms from damaged fibres. Transient hepatic dysfunction with elevated serum bilirubin concentration and prolonged prothrombin time has been reported in a series of patients with non-traumatic rhabdomyolysis. ${ }^{23}$ Under such circumstances, where there is probably a true dysfunction - a transient rise in serum $\alpha$-GST concentrations is likely.

Although immunohistochemical studies have shown that $\alpha$-GST is detectable in the normal human kidney, ${ }^{3}$ we found no relationship between serum $\alpha$-GST and creatinine concentrations: $\alpha$-GST concentrations were within the reference range in $\mathbf{3 1}$ of $\mathbf{3 3}$ samples from patients with renal dysfunction. There was no clinical explanation for the abnormal serum $\alpha$-GST measurements in the two patients. The elevated enzyme levels could be due to active kidney tissue damage. The patient with the highest serum $\alpha$-GST was receiving digoxin therapy. The serum concentration of digoxin, however, was not at concentrations likely to cause acute nephrotoxicity. The detection of increased $\alpha$-GST concentrations in urine has been reported to provide a measure of proximal tubular damage in patients with raised serum creatinine levels attributed to cyclosporin-induced nephrotoxicity ${ }^{24}$ but this is not reflected in increased serum concentrations. A more likely explanation for the raised serum $\alpha$-GST in this case was perhaps mild occult liver disease as the patient also had the highest serum ALT activity of all 33 patients with renal failure.

The serum $\alpha$-GST concentration in patients with rheumatoid arthritis and a raised serum CRP was not significantly different from that in patients with a normal CRP or healthy blood donors-confirming that $\alpha$-GST is not a nonspecific marker of inflammation. However, this study did alert us to a potentially important assay interference. Raised serum concentrations of $\alpha$-GST were found in four patients and all four of these patients had normal CRP but raised IgM rheumatoid factor titres. In two cases, assay interference was confirmed by over recovery of added $\alpha$-GST. It is well recognized that in immunoassays IgM rheumatoid factor can give rise to falsely elevated levels of analyte by binding to the Fc portions of the capture and/or detection antibodies. ${ }^{25-27}$ Methods of sample pretreatment to overcome this analytical problem have been described, ${ }^{28,29}$ but these are time-consuming. Reduction of the capture antibody to its Fab fragments ${ }^{6}$ or use of avian capture/detection antibodies ${ }^{26}$ may be better options.

In our previous study we observed highly erratic changes in daily $\alpha$-GST measurements in a transplant recipient ${ }^{5}$ and assay interference by serum was suspected. This interference was confirmed from the over-recovery $(>100 \%)$ of added $\alpha$-GST. Interference was probably attributable to the presence of low concentrations $(<5 \mathrm{~g} / \mathrm{L})$ of an IgM paraprotein in the serum-a recognized potential source of interference in immunoassays. ${ }^{30}$ In eight samples from nontransplant recipients with $\operatorname{IgG}, \operatorname{IgA}$ and $\operatorname{IgM}$ paraproteins, at concentrations up to $64 \mathrm{~g} / \mathrm{L}$, 
no interference in the $\alpha$-GST immunoassay was observed suggesting that this interference is rare. Indeed, this was the only instance of interference out of more than 4000 samples tested.

It is known that GSTs have a bilirubin binding capacity which can interfere with activity measurements of the enzyme in serum. ${ }^{2}$ It was, therefore, necessary to exclude the possibility that bilirubin may also affect the $\alpha$-GST immunoassay. This would be particularly relevant in liver transplant recipients in whom serum bilirubin levels may exceed $500 \mu \mathrm{mol} / \mathrm{L}$. Although there was a small (average 6\%) under-recovery of $\alpha$-GST spiked into icteric samples, there was no evidence of concentration-dependent interference by bilirubin at concentrations up to $591 \mu \mathrm{mol} / \mathrm{L}$. It was also established that the assay was not susceptible to interference by either hyperlipidaemia or gross haemolysis.

In conclusion, monitoring serum $\alpha$-GST offers several clinical advantages over conventional transaminase measurements as a marker of hepatocellular damage. In particular, the enzyme has a short in vivo half-life-allowing improved discrimination of acute changes in liver function over time. The test may also be more liver specific than the transaminases. Although this immunoassay is not as rapid as those used for conventional transaminase enzyme activity, it can be completed within $2 \cdot 25 \mathrm{~h}$ and assay precision is satisfactory for routine daily monitoring.

\section{REFERENCES}

1 Beckett JB, Hayes JD. Plasma glutathione S-transferase measurements and liver disease in man. J Clin Biochem Nutr 1987; 2: 1-24

2 Beckett JB, Hayes JD. Glutathione S-transferase: biomedical applications. Adv Clin Chem 1993; 30: 281-379

3 Sundberg AGM, Nilsson R, Appelkvist E-L, Dallner G. Immunohistochemical localization of $\alpha$ and $\pi$ class glutathione transferases in normal human tissues. Pharmacol Toxicol 1993; 72: 321-31

4 Mannervok B, Awasthi YC, Board PG, Hayes JD, Dillio C, Ketterer B, et al. Nomenclature for human glutathione transferases. Biochem $J$ 1992; 282: 305-6

5 Trull AK, Facey SP, Rees GW, Wight DGD, Noble-Jamieson G, Joughin C, et al. Serum alpha-glutathione $\mathrm{S}$-transferase: a sensitive marker of hepatocellular damage associated with liver allograft rejection. Transplantation 1994; 58: 1345-51

6 Beckett GJ, Foster GR, Hussey AJ, Oliveira DBG, Donovan JW, Prescott LF, et al. Plasma glutathione $S$-transferase and $F$ protein are more sensitive than alanine aminotransferase as markers of paracetamol (acetaminophen)-induced liver damage. Clin Chem 1989; 35: 2186-9
7 Beckett GJ, Chapman BJ, Dyson EH, Hayes JD. Plasma glutathione S-transferase measurements after paracetamol overdose: evidence for early hepatocellular damage. Gut 1985; 26: 26-31

8 Sherman M, Bass NM, Campbell JAH, Kirsch RE. Radioimmunoassay of human ligandin. Hepatology 1983; 3: 162-9

9 Hayes PC, Hayes JD, Hussey AJ, Bouchier IAD, Beckett GJ. Changes in plasma glutathione S-transferase B1 concentrations after alcohol ingestion in man: a measure of hepatocellular sensitivity to chronic alcohol excess. Clin Chem Enzyme Commun 1990; 2: 189-94

10 Howie AF, Patrick AW, Fisher BM, Collier A, Frier BM, Beckett GJ. Plasma glutathione S-transferase concentrations after insulin-induced hypoglycaemia in normal subjects and diabetic patients. Diabetic Med 1989; 6: 224-7

11 Beckett GJ, Hussey JE, Laing I, Howie AF, Hayes JD, Strange RC, et al. Measurements of glutathione S-transferase B1 in plasma after birth asphyxia: an early indication of hepatocellular damage. C/in Chem 1989; 35: 995-9

12 Murray JM, Rowlands BJ, Trinick TR. Indocyanine green clearance and hepatic function after prolonged anaesthesia; comparison of halothane with isoflurane. Br J Anaesth 1992; 68: 168-71

13 Murray JM, Trinick TR. Hepatic function and indocyanine green clearance during and after prolonged anaesthesia with propofol. $B r J$ Anaesth 1992; 69: 643-4

14 Soloway RD, Summerskill WHJ, Boggenstoss AH. Clinical biochemical and histological remission of severe chronic active liver disease. Gastroenterol 1972; 63: 820-33

15 Hayes PC, Bouchier IAD, Beckett GJ. Glutathione S-transferases in humans in health and disease. Gut 1991; 32: 813-18

16 Hayes PC, Hussey AJ, Keating J, Bouchier IAD, Williams $R$, Beckett GJ, et al. Glutathione S-transferase levels in autoimmune chronic active hepatitis: a more sensitive index of hepatocellular damage than aspartate transaminase. Clin Chim Acta 1988; 172: 211-16

17 Tiainen P, Karhi KK. Ultrasensitive time-resolved immunofluorometric assay of glutathione $\mathrm{S}$ transferase alpha in serum. Clin Chem 1994; 40: 184-9

18 Raggatt PR. Duplicates or singletons? An analysis of the need for replication in immunoassay and a computer program to calculate the distribution of outliers, error rate and the precision profile from assay duplicates. Ann Clin Biochem 1989; 26: 26-37

19 Van der Meulen JH, Kuipers H, Drukker J. Relationship between exercise-induced muscle damage and enzyme release in rats. $J$ Appl Physiol 1991; 71: 999-1004

20 Valentine BA, Blue JT, Shelley SM, Cooper BJ. lncreased serum alanine aminotransferase activity associated with muscle necrosis in the $\operatorname{dog} . J$ Vet Intern Med 1990; 4: 140-3

21 Malinoski FJ. Strenuous exercise simulating hepatic injury during vaccine trials. Vaccine $1992 ; 10$ : 39-42 
22 Friden J, Sfakianos PN, Hargens AR. Blood indices of muscle injury associated with muscle contractions. J Orthop Res 1989; 7: 142-5

23 Akmal M, Massry SG. Reversible hepatic dysfunction associated with nontraumatic rhabdomyolysis. $\mathrm{Am}$ J Nephrol 1990; 10: 49-52

24 Sundberg AGM, Appelkvist E-L, Backman L, Dallner $G$. Urinary $\pi$-class glutathione transferase as an indicator of tubular damage in the human kidncy. Nephron 1994; 67: 308-16

25 Banks RE, Evans SW, Taylor KF, Bird HA, Whicher JT. Measurement of plasma concentrations of polymorphonuclear elastase- $\alpha$ proteinase inhibitor (elastase- $\alpha_{1}$ antitrypsin) in patients with rheumatoid arthritis: interference by rheumatoid factor. Ann Rheum Dis 1990; 49: 18-21

26 Larsson A, Karlsson-Parra A, Sjöquist J. Use of chicken antibodies in enzyme immunoassays to avoid interference by rheumatoid factors. Clin Chem 1991; 37: $411-14$
27 Borque L, Elena A, Maside C, Rus A, Del Cura J. Rheumatoid arthritis and hepatitis $\mathrm{C}$ virus antibodies. Clin Exp Rheumatol 1991; 9: 617-19

28 Carrol GJ, Bell MC. IgM class immunoglobulin with high rheumatoid factor activity interferes with the measurement of interleukin $1 \beta$. J Rheumatol 1991; 18: $1266-9$

29 Malyak M, Joslin FG, Verderber EL, Eisenberg SP, Arend P. IL-1 ra ELISA: reduction and alkylation of synovial fluid eliminates interference by IgM rheumatoid factors. J Immunol Meth 1991; 140: 281-8

30 Galou G, Legras B, Ruelland A, Grosbois B, Cloarec L. Problems of C-reactive protein determinations in patients with monoclonal immunoglobulins. Clin Chem 1993; 39: 918

Accepted for publication 25 May 1995 